KLAUDIA GAJDA

\title{
Factors shaping inter- organizational trust in e-commerce based on literature review
}

Klaudia Gajda, M.A., University of Zielona Góra, Management and Quality Sciences,

\section{Introduction}

For many years, attempts have been made to diagnose the phenomenon occurring in the interactions between e-commerce enterprises, both in economics, sociology, and psychology (Ryciuk, 2013). This phenomenon, especially in the B2B (business to business) approach, is fundamental and is an inseparable element in building relationships between business partners, contributing to the success of any enterprise, namely- „inter-organizational trust" (Koźmiński, 2014).

Due to the market, which is characterized by a high degree of risk and lack of trust, trust is the basic determinant that stimulates interaction between enterprises (Doney and Cannon, 1997). "Trust contributes to strong interpersonal, intra-organizational and interorganizational relationships" (Sahay, 2003, p. 556). In relation to the electronic business environment, inter-organizational trust means building confidence in the purchase of goods or services online, i.e. the online environment (Xiao et al., 2016). This issue becomes even more important because the exchange of relationships is based on the impersonal nature of Internet infrastructure. The physical and 
temporal distance between buyers and sellers, possible delays between purchase and delivery, information discrepancies between the parties to the exchange and the requirement to share confidential personal data and financial information at the time of the transaction make trust necessary to maintain relationships with buyers (Xiao et al., 2016).

On the basis of the literature review carried out in accordance with the recommendations of W. Czakon (book, entitled: „Podstawy metodologii badan w naukach o zarządzaniu"), thirteen research reports have been selected that relate to factors shaping inter-organizational trust in e-commerce. In this article, based on the scientific achievements of these studies, an attempt was made to show the structure of trust, which is presented in four spheres and in a different definition of light. Such areas are characterized by benevolence trust (Ando and Rhee, 2009), integrity trust (Chen et al. 2015), competence trust (Ellonen et al. 2008) and general trust (Mukherjee, 2012). The purpose of the article is to isolate from these spheres, based on the results of research published in world literature, external and internal factors shaping the level of inter-organizational trust in e-commerce (B2B and B2C).

\section{Inter-organizational trust based on four spheres of functioning in e-commerce}

Due to the unique nature of inter-organizational trust in e-commerce, many definitions have been developed (table 1) to define its subject matter.

For the purposes of this study, an approach was used to show interorganizational trust from four perspectives, i.e.:

- benevolence trust (Ando and Rhee, 2009),

- integrity trust (Chen et al. 2015),

- competence trust (Ellonen et al. 2008)

- general trust (Mukherjee, 2012).

Chowdhury (2005, p. 3) stated that "trust based on benevolence, i.e.: positive feelings, has a spectacular impact on creating strong ties between businesses in e-commerce”, and "benevolence" is the readiness to be open to the anxiety of the other side of the interaction and to try to demonstrate ways that will eventually overcome him. Benevolence trust can have a binding effect on e-commerce partners (Leaquiddin et al. 2010).

Organizational integrity means that e-business websites are honest in all interactions that involve obligations to their partners. Wrightsman (1964, p. 745) stated that "trust is the expectation of how people behave towards others. Trustworthiness represents the extent to which people are considered to be

Factors shaping inter-organizational trust in e-commerce based on literature review 
fairly honest, unlike the immoral and irresponsible”. „Trust based on integrity is the expectation that the other party to e-commerce will perform a specific action on the trustee, regardless of the ability to monitor or controlling transactions (Barney and Hansen, 1994). Trust based on integrity is a system of rules, norms, and regulations, owing to which participants of e-exchange will feel safe and believe that each party will properly fulfill their obligations.

Trust built on the competences of B2B e-commerce partners is presented as trust-based on qualifications and professional experience as well as specialist knowledge in the production of goods or the provision of services for which demand is reported (Coulter and Coulter, 2002). Inter-organizational trust is distinguished by many factors that characterize organizations in individual or whole relationships between them. It is important, however, that organizations actively participating in e-commerce rely on trust, which builds, among others, the competences of the parties (buyers - sellers).

Companies involved in e-commerce, strive to achieve tangible benefits based on continuous cooperation with other companies. However, for such a result to take place for each participant, one should adapt to all conditions prevailing in the environment of both the e-seller and e-recipient. Thanks to this, each participant will feel special, will be covered by the care and respect of the business partner, which will strongly affect the building and maintaining interorganizational trust.

Inter-organizational trust is presented in a different definition of light and because of the important spheres consist of them strictly. Their spheres have a number of factors whose implementation in the "life" of an e-company is of great importance for both the buyer and the seller, and trough their use, none of the parties to the interaction will experience "harm" during the interaction process in e-commerce. Such factor is presented in the results of research carried out on the basis of selected thirteen research reports (table 2).

Therefore, it can be stated that trust in the inter-organizational environment in e-commerce is nothing but faith in the future activities of others (Smith, 2010), which trough the prism of compliance with certain norms and values promotes obtaining tangible benefits that will be achieved by cooperating companies.

\section{External and internal factors shaping inter-organizational trust in e-commerce}

To identify the factors shaping inter-organizational trust, the achievements of various researchers were used. The electronic articles places in the following 
databases were reviewed: EBSCO, PROQUEST, ELSEVIER, SAGE, JSTOR, WILEY, EMERALD, TAYLOR \& FRANCIS. The research covered the period from 2000-2020. The following keywords were applied: trust, e-commerce, factors, inter-organizational, B2B, B2C. After the search, 276 articles were obtained. Conceptual work was excluded from the research and in this way, a collection of 40 articles of the nature of research reports was obtained. Then the articles that were not related to factors closely affecting inter-organizational trust were rejected. Finally, 13 research articles were adopted for analysis regarding internal and external factors affecting inter-organizational trust in e-commerce (B2B and B2C).

In purpose to determine internal and external factors shaping interorganizational trust in e-commerce, the researcher conducted an analysis, thanks to which they were presented in tabular form:

1. Results regarding the understanding of "inter-organizational trust", shared into spheres of operations in e-commerce (table 1).

2. External and internal factors shaping inter-organizational trust (table 2).

3. Factors shaping inter-organizational trust in e-commerce, shared by frequency (table 3).

Table 1. Results regarding the understanding of „inter-organizational trust", shared into spheres of operations in e-commerce

\begin{tabular}{|c|c|c|}
\hline Author & $\begin{array}{c}\text { Type of } \\
\text { trust }\end{array}$ & Definition of trust \\
\hline \multirow{3}{*}{ 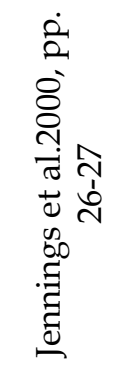 } & $\begin{array}{l}\text { Benevolen- } \\
\text { ce trust }\end{array}$ & $\begin{array}{l}\text { "Trust is not a commodity to be bought or sold in the marketplace, } \\
\text { but rather must be developed over time based on a series of positive } \\
\text { experciences between individuals" }\end{array}$ \\
\hline & $\begin{array}{l}\text { Integrity } \\
\text { trust }\end{array}$ & $\begin{array}{l}\text { "Trust has been defined as mutual confidence that no party ti an exchenge } \\
\text { will behave opportunistically and exploit another's vulnerabilities" }\end{array}$ \\
\hline & $\begin{array}{c}\text { General } \\
\text { trust }\end{array}$ & $\begin{array}{l}\text { "The development of trust between alliance partners can also be influenced } \\
\text { by the culture of the alliance participants" }\end{array}$ \\
\hline \multirow{2}{*}{ 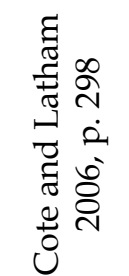 } & $\begin{array}{l}\text { Integrity } \\
\text { trust }\end{array}$ & $\begin{array}{l}\text { "Trust mitigates the need for costly monitoring systems to insure that one } \\
\text { side of the dyad is not exploiting the other" }\end{array}$ \\
\hline & $\begin{array}{c}\text { General } \\
\text { trust }\end{array}$ & $\begin{array}{l}\text { "Trust serves multiple roles within inter-firm interactions from willingness } \\
\text { to axquiesce to demands from either side of the dyad to the development of } \\
\text { longer term commitment to mutual performence outcomes" }\end{array}$ \\
\hline
\end{tabular}

Factors shaping inter-organizational trust in e-commerce based on literature review 


\begin{tabular}{|c|c|c|}
\hline 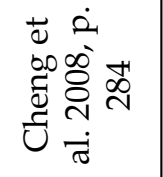 & $\begin{array}{c}\text { General } \\
\text { trust }\end{array}$ & $\begin{array}{l}\text { "Trust between trading partners is a key faciliator of inter-firm relationships } \\
\text { for the success of business afillation"; , ,Trust is one of the important factors } \\
\text { in influencing trading partners to adopt the technology" }\end{array}$ \\
\hline 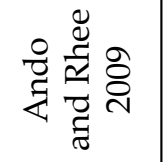 & $\begin{array}{c}\text { General } \\
\text { trust }\end{array}$ & $\begin{array}{l}\text { "Interorganizational trust is positively associated with higher performance } \\
\text { in relational exchanges" }\end{array}$ \\
\hline 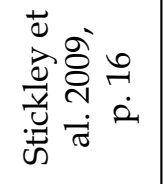 & $\begin{array}{l}\text { Competen- } \\
\text { ce trust }\end{array}$ & "Trust is associated with a range of social phenomena such as democracy" \\
\hline 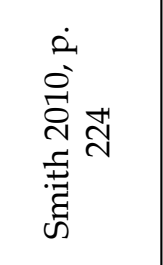 & $\begin{array}{l}\text { Integrity } \\
\text { trust }\end{array}$ & $\begin{array}{l}\text { "Trust is the belief concerning the action that is to be expected from others. } \\
\text { The belief refers to probabilities that other will do certain things or refrain } \\
\text { from doing certain things, which in either case affects the well-being of } \\
\text { the gholder of the belief, as well as possibly the well-being of others or } \\
\text { a relevent collectivity"; "Trust is a bet on the future contingent action of } \\
\text { others" }\end{array}$ \\
\hline \multirow{2}{*}{ 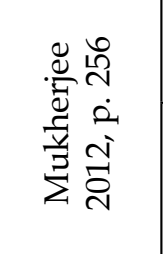 } & $\begin{array}{l}\text { Integrity } \\
\text { trust }\end{array}$ & $\begin{array}{l}\text { "Trust exist when one party has confidence in the exchange partner's } \\
\text { reliability and integrity" }\end{array}$ \\
\hline & $\begin{array}{l}\text { General } \\
\text { trust }\end{array}$ & $\begin{array}{l}\text { "Trust can reduce transaction costs and also can be an antencedent of } \\
\text { cooperative bahavior"; "Trust is considered a central feature of any } \\
\text { strategic partnership" }\end{array}$ \\
\hline \multirow{4}{*}{ 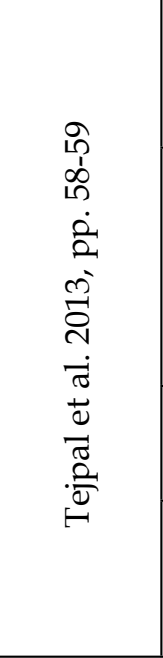 } & $\begin{array}{l}\text { Benevolen- } \\
\text { ce trust }\end{array}$ & $\begin{array}{l}\text { "The trust factors empathy and politeness, together with being warm and } \\
\text { friendly, can maintain and build trust when supply chain partners are } \\
\text { involved in regular interaction". }\end{array}$ \\
\hline & $\begin{array}{l}\text { Competen- } \\
\text { ce trust }\end{array}$ & $\begin{array}{l}\text { "Trust in supply chain can be related to the members' competence or } \\
\text { work standard, skill, knowledge and ability to fulfill a promise, agreement } \\
\text { ir bligation. Mutual trust between supply chain partners is built on the } \\
\text { trust in, and acknowledgement of, the competence of the other partner to } \\
\text { provide goods or services customized to their requirements" }\end{array}$ \\
\hline & $\begin{array}{l}\text { Integrity } \\
\text { trust }\end{array}$ & $\begin{array}{l}\text { "Supply chain partnerships are built on the trust that their partners pursue } \\
\text { shared values or compatible goals" }\end{array}$ \\
\hline & $\begin{array}{l}\text { General } \\
\text { trust }\end{array}$ & $\begin{array}{l}\text { "Maintaining and building trust between supply chain partners relies } \\
\text { on continued commitment to communication together with sharing } \\
\text { information and planning" }\end{array}$ \\
\hline 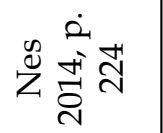 & $\begin{array}{c}\text { General } \\
\text { trust }\end{array}$ & $\begin{array}{l}\text { "Trust is an important ingredient for successful learning and for } \\
\text { developing new knowledge, which is a central factor in the stages theories } \\
\text { of internationalization" }\end{array}$ \\
\hline
\end{tabular}




\begin{tabular}{c|c|l} 
Competen- & "Low trust mayk make partnering firms hide their proprietary knowledge \\
from each other, and thus discorage co-exploitation"
\end{tabular}

Source: own study based on accepted thirteen research reports

Table 1 presents selected definitions of the authors' trust, thirteen research reports accepted for analysis. The table presents the definitions of trust, i.e.: benevolence trust, integrity trust, competence trust, and general trust. All these spheres form the broadly understood concept of "inter-organizational trust".

Table 2. External and internal factors shaping inter-organizational trust

\begin{tabular}{|c|c|c|c|}
\hline Authors & $\begin{array}{c}\text { Types of } \\
\text { inter-orga- } \\
\text { nizational } \\
\text { trust }\end{array}$ & Factor type & $\begin{array}{l}\text { A group of } \\
\text { factors }\end{array}$ \\
\hline $\begin{array}{c}\text { Jennings et al. 2000; Tejpal } \\
\text { et al. } 2013\end{array}$ & $\begin{array}{l}\text { Benevolence } \\
\text { trust }\end{array}$ & openness; politeness and benevolence & Internal \\
\hline $\begin{array}{l}\text { Jennings et al. 2000; Smith } \\
\text { 2010; Tejpal et al. 2013; Xiao } \\
\text { et al. } 2016\end{array}$ & $\begin{array}{l}\text { Integrity } \\
\text { trust }\end{array}$ & $\begin{array}{l}\text { credibility; honesty and integrity; } \\
\text { reliability; confidentiality; security } \\
\text { protection }\end{array}$ & Internal \\
\hline
\end{tabular}

Factors shaping inter-organizational trust in e-commerce based on literature review 


\begin{tabular}{c|c|c|c}
$\begin{array}{c}\text { Cote i Latham, 2006; } \\
\text { Stickley et al. 2009; Smith, } \\
\text { 2010; Tejpal et al. 2013; Sun } \\
\text { i Lo, 2014; Cheng et al. 2015; } \\
\text { Mirkovski et al. 2016 } \\
\text { trust }\end{array}$ & $\begin{array}{c}\text { opportunistic behavior; degree } \\
\text { of education; motivation and } \\
\text { competence; experience and } \\
\text { qualifications, conformity; exploitation } \\
\text { and exploration framework; } \\
\text { learning ability; power; contractual } \\
\text { management; relational management }\end{array}$ & Internal \\
\hline $\begin{array}{c}\text { Stickley et al. 2009; Smith, } \\
\text { 2010; Chen et al. 2015 }\end{array}$ & General trust & $\begin{array}{c}\text { economic difficulties; social relations; } \\
\text { perceived (by the buyer) website } \\
\text { quality, trust in Platform }\end{array}$ & External \\
\hline $\begin{array}{c}\text { Jennings et al. 2000; Ando } \\
\text { i Rhee, 2009; Stickley } \\
\text { et al. 2009; Smith, 2010; } \\
\text { Mukherjee, 2012; Tejpal et } \\
\text { al. 2013; Nes, 2014; Cheng } \\
\text { et al. 2015; Mirkovski et al. }\end{array} \quad$ General trust & $\begin{array}{c}\text { partner reputation ; explicit and } \\
\text { implicite rulet (after conclusion of the } \\
\text { contract); exchange of information } \\
\text { (after conslusion of the contrach); } \\
\text { division of benefits and risks (after } \\
\text { the conclusion if the contract); } \\
\text { involvement (after the conclusion } \\
\text { of the contrach); common values; } \\
\text { communication; joint decision-making } \\
\text { process; cultural adaptation; fair } \\
\text { distribution of bargaining power; } \\
\text { ethnicity; economic optimism; } \\
\text { expections and values; information } \\
\text { sharing; performance; collaboration }\end{array}$ & Internal \\
\hline
\end{tabular}

Source: own study based on accepted thirteen research reports

Table 2 illustrates the types of factors cited by the authors of the thirteen adopted for the analysis of research reports. The types of factors placed in the table are adequate to individual types of trust and matched due to two groups of factors shaping inter-organizational trust, namely: the group of external factors and the group of internal factors.

Table 1 and table 2 show some kind of relationship with each other. This is the state of affairs, because each, selected definition, divided into individual areas of trust, included in table 1 , finds its reference in table 2, considering the type and group of factors it contains. Therefore: Benevolence trust, defined as "trust that is not a good bought or sold on the market, but rather needs to be developed over time into a series of positive experiences between people" (Jennings et al. 2000, p. 27). It can also be stated that „empathy and politeness, as well as being warm and friendly, can maintain and build trust when supply chain partners participate in regular interactions" (Tejpal et al. 2013, p. 58). This type of trust 
is demonstrated by factors such as openness, politeness or benevolence, which belong to the group of internal factors (table 2).

Integrity trust is defined as: „belief in the action to be expected from others will do or refrain from doing something, which in each case will affect the good of the belief holder, as well as the good of others or the right collectivity", or "trust is faith in the future action of others" (Smith 2010, p. 224). A different understanding of integrity trust is provided in the statement "supply chain partnerships are based on the trust that their partners pursue common values or consistent goals" (Tejpal et al. 2013, p. 58). Therefore, this type of trust is based on such factors as credibility, honesty and integrity, reliability, confidentiality, and security protection. The types of integrity trust identify with the internal group of internal factors (table 2).

The next sphere of trust is competence trust. Such trust is distinguished by a definition, i.e.: „trust in the supply chain can be related to the competences or standard of work of members, skills, knowledge and the ability to fulfill a promise, agreement or commitment. „Mutual trust between supply chain partners is based on trust in another partner in providing foods or services tailored to their requirements"' (Tejpal et al. 2013, p. 58).

A group of factors characterizing their types, i.e.: opportunistic behavior, degree of education, motivation and competence, experience and qualifications, conformity, exploitation and exploration framework, learning ability, power, contractual management, relational management are a group of internal factors (table 2).

The last sphere of inter-organizational trust is general trust. General trust, trough the prism of the analyzed research reports, is divided into two groups of factors, namely:

- external factors (economic difficulties, social relations, perceived (by the buyer) website quality, trust in the platform), (table 2),

- internal factors (partner reputation, explicit and emplicit rules (after the conclusion of the contract), exchange of information (after the conclusion of the contract), involvement (after the conclusion of the contract), common values, communication, join decision-making process, cultural adaptation, fair distribution of bargaining power, ethnicity, economic optimism, expectations and values, information sharing, performance, collaboration), (table 2).

In definitional light, inter-organizational trust in the sphere of general trust is considered to be the "central feature of any strategic partnership" (Mukherjee 2012, p. 256). "Trust is a subjective belief that the trusting party believes that the 
trusted party will behave, showing honesty, skills, and kindness" (Chen et al. 2015, p. 263). Other definitions state that "trust is an important component of successful learning and the development of new knowledge, which is a major factor in the stages of internationalization theory" (Nes 2014, p. 224), and "in the context of e-business, trust is becoming an even more important issue because the exchange of relationships is based in the impersonal nature of infrastructure" (Xiao et al. 2016, p. 434).

In the era of electronic business, there are many factors that can improve interactions between enterprises. Table 3 presents a number of factor trough which business partners will achieve a satisfactory level of trust. The factors presented in tabular form are presented in terms of their frequency of occurrence in the thirteen analyzed research reports.

The table shows that the best-seen factor of trust that companies will use in relation to their partners in e-commerce are internal factors determined by competence trust, namely- experience and qualifications, the number of repetitions in research reports is $2 / 13$. The next internal factors are those that find their place in the type of inter-organizational trust, which is general trust, i.e.: common values of- 5 repetitions per 13 research reports) and communication- 4 repetitions per 13 research reports. Other factors presented in the table obtained the result "1".

Table 3. Factors shaping inter-organizational trust in e-commerce, shared by frequency

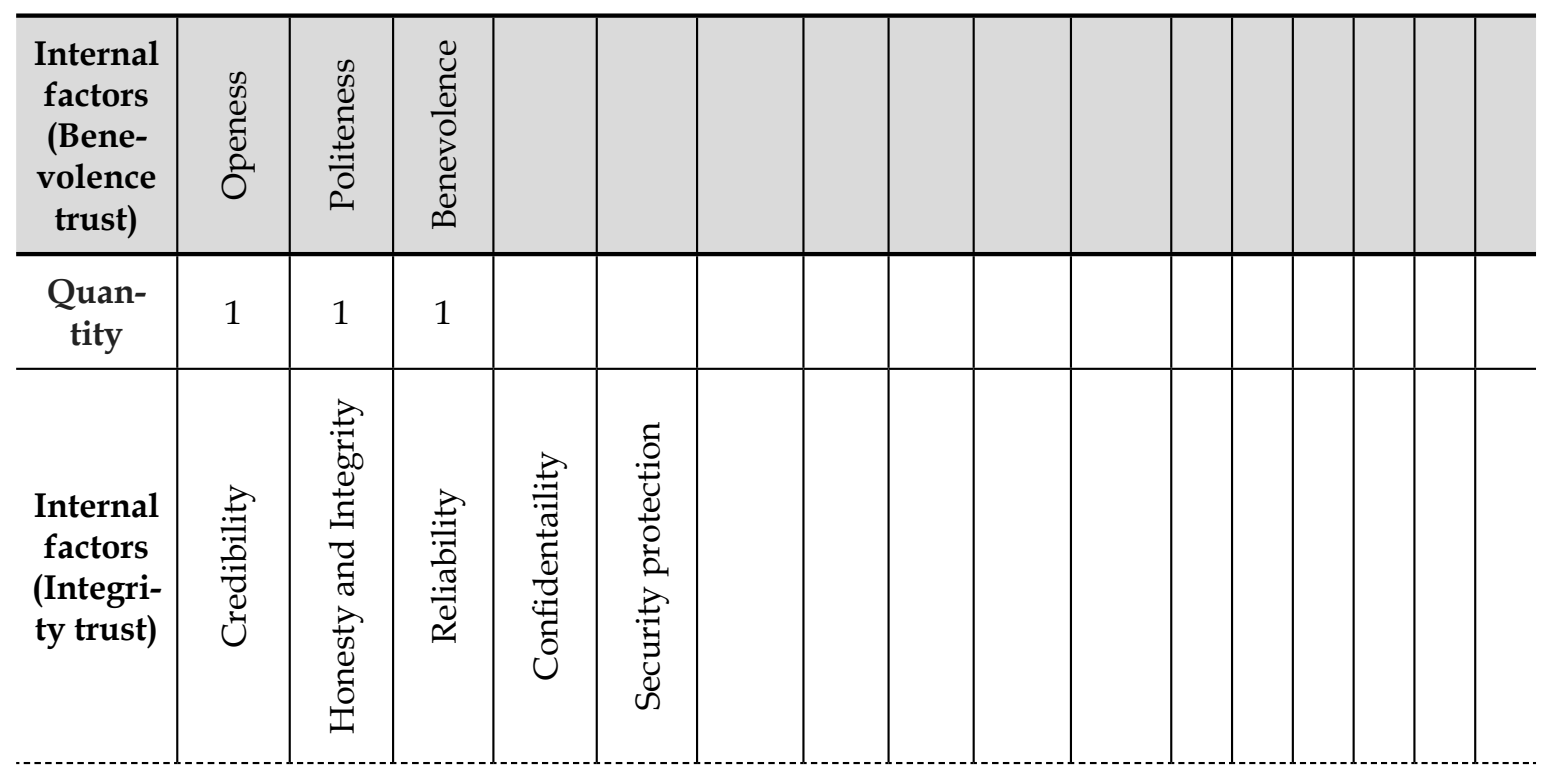

KLAUDIA GAJDA 
Management

2020

Vol. 24, No. 1

\begin{tabular}{|c|c|c|c|c|c|c|c|c|c|c|c|c|c|c|c|c|}
\hline $\begin{array}{c}\text { Quan- } \\
\text { tity }\end{array}$ & 1 & 1 & 1 & 1 & 1 & & & & & & & & & & & \\
\hline $\begin{array}{c}\text { Internal } \\
\text { factors } \\
\text { (Com- } \\
\text { petence } \\
\text { trust) }\end{array}$ & 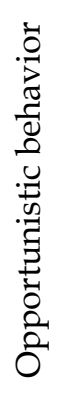 & 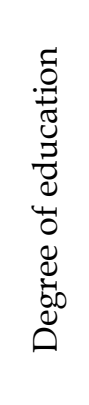 & 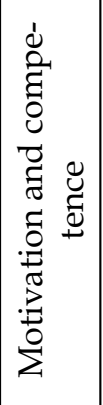 & 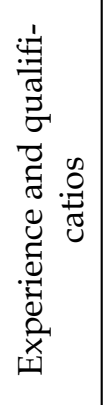 & 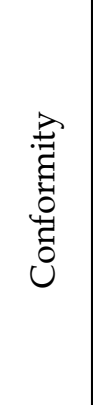 & 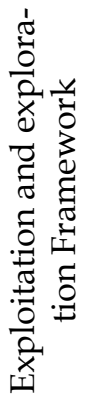 & 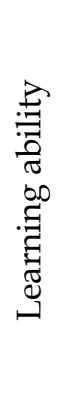 & $\begin{array}{l}\dot{0} \\
3 \\
0 \\
0\end{array}$ & 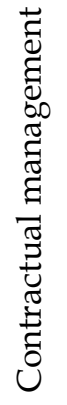 & 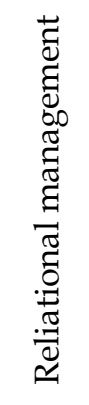 & & & & & & \\
\hline $\begin{array}{c}\text { Quan- } \\
\text { tity }\end{array}$ & 1 & 1 & 1 & 2 & 1 & 1 & 1 & 1 & 1 & 1 & & & & & & \\
\hline $\begin{array}{c}\text { External } \\
\text { factors } \\
\text { (General } \\
\text { trust) }\end{array}$ & 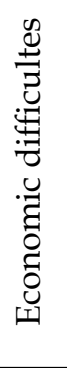 & 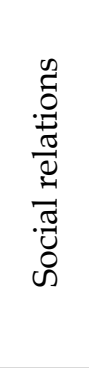 & 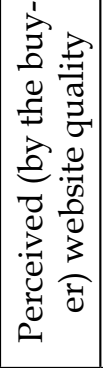 & 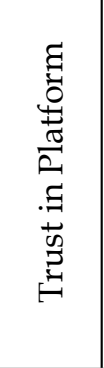 & & & & & & & & & & & & \\
\hline $\begin{array}{c}\text { Quan- } \\
\text { tity }\end{array}$ & 1 & 1 & 1 & 1 & & & & & & & & & & & & \\
\hline $\begin{array}{c}\text { Internal } \\
\text { factors } \\
\text { (General } \\
\text { trust) }\end{array}$ & 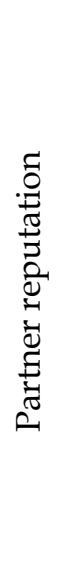 & 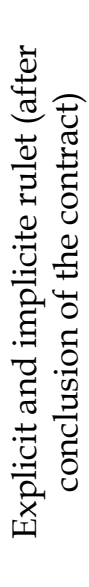 & 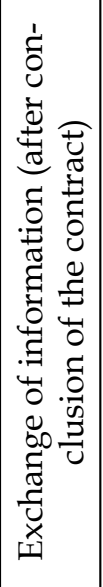 & 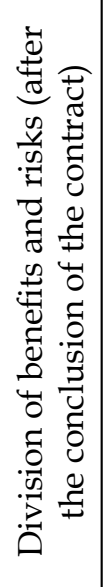 & 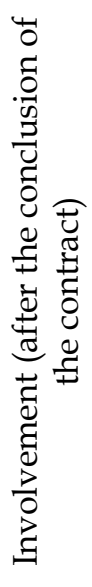 & 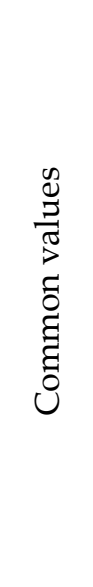 & 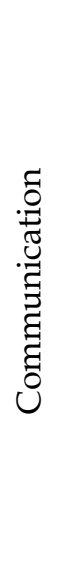 & 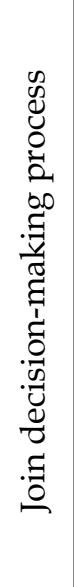 & 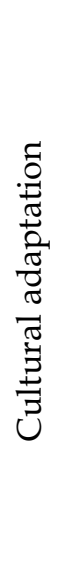 & 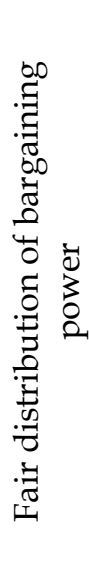 & 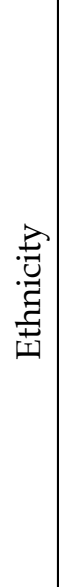 & 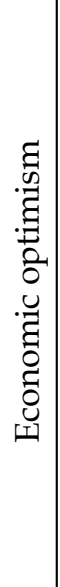 & 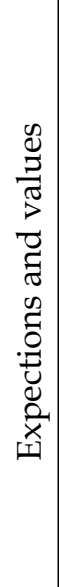 & 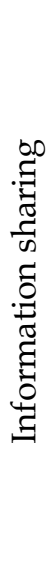 & 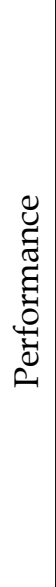 & 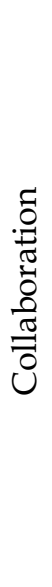 \\
\hline $\begin{array}{c}\text { Quan- } \\
\text { tity }\end{array}$ & 1 & 1 & 1 & 1 & 1 & 5 & 4 & 1 & 1 & 1 & 1 & 1 & 1 & 1 & 1 & 1 \\
\hline
\end{tabular}

Source: own study based on accepted thirteen research reports

Factors shaping inter-organizational trust in e-commerce based on literature review 


\section{Discussion}

Based on the analysis of thirteen research reports, a number of very important external and internal factors that facilitate the development of interorganizational trust in e-commerce are presented.

All factors determining B2B trust in e-commerce are of key importance for business partners, e.g.: openness, as an internal factor conditioning trust (Jennings et al. 2000), refers to the to which interaction partners Express, e.g.: their ideas. "Openness" between business parties allows for free discussion and a more efficient settlement of possible problems (Jennings et al. 2000). Honesty and integrity are the values by which a company can "attract" new business partners. These values are very important for establishing lasting relationships based on trust (Jennings et al. 2000). Another factor why B2B relationships are built trough trust is credibility (Smith, 2010). E-companies can shape various credibility signals, i.e.: values, norms, goals or expectations, which for their contractors play a key role in the context of inter-organizational trust.

Other important factors for business partners are internal factors, i.e.: joint decision-making, cultural adaptation and a fair distribution of bargaining power (Ando and Rhee, 2009), because it demonstrates the justice that characterizes an organization. Cultural adaptation is a key aspect, especially in organizations cooperating with partners from various cultures. It is a cultural adaptation national culture of the business partner that aims to understand, learn and adapt to the, where such cooperation exists. This adaptation not only builds a deep understanding but also minimizes conflicts that may arise due to cultural differences. This adaptation leads to an attitude of contractors as an expression of respect and care (Ando and Rhee, 2009). Research also shows that company results are greatly influenced by inter-organizational relationships, which are largely influenced by the performance of the partners with whom they work. A company that is efficient in its operations thus proves that it is worthy to trust it (Nes, 2014). On the electronic level, building trust in an e-company selling products or services consists of factors such as the quality of the website perceived by the customer and trust that takes place across the entire platform (Chen et al. 2015). It is important that the website is covered by all rules and regulations. This has a significant impact on the reception of such a site from the customer's perspective. Trust is also built when the requirements of one of the parties (the buyer) are met as a result of previous transactions. The seller will be trusted if his website contains the opinions of e-companies that have had the opportunity to cooperate with him. 
However, the results of the analysis showed that the factors that best influence the level of trust in the electronic exchange are: "common values", "communication" and "experience and qualifications".

Common values have become a precursor to joint involvement in interorganizational cooperation. When the page values are the same or similar, the conditions in the companies will be accepted and the interactions will be smooth, which will lead to their better development in e-commerce.

Communication, as another important factor in e-commerce, is the basis for building trust and revers to the formal and informal sharing of information and all plans, but also past experiences (Cote and Latham, 2006). Communication provides a satisfactory environment for inter-organizational relationships in e-commerce, without which such relationships can "suffer" (Mukherjee, 2012). Enterprises are more willing to cooperate in the company's network based on experience, professional qualifications, specialized knowledge that is related to the knowledge of the production of goods, or the provision of desired services (Tajpal et al. 2013). It is also worth adding that puts more emphasis on the competences of its business partners, on their reliability and references than on the motive of their action (Smith, 2010). Through the interaction between participants of e-commerce based on inter-organizational trust in the sphere of competence, it can be concluded that such relationships, in the conviction of business partners, will affect a better reception in the context of the type of needs reported, both goods and services. Each delivery will be associated with high quality and professionalism on the part of the e-supplier. Thanks to this procedure, participants of e-commerce can expect positive publicity about their business, which will translate into their impeccable reputation, expanding the supply chain, greater opportunities, better relationships with existing business partners and opportunities to attract new exchange partners in e-commerce. The competences of employees and management build trust in relationships. The more qualified the staff, the greater the confidence in the quality and safety of cooperation. Thanks, competences, we can assess the credibility of the other party to the relationship.

Summing up the previous considerations, it can be stated that building interorganizational trust in e-commerce is a complex process, due to its individual spheres and conditioning by a number of external and internal factors.

Trust is an added value that should be constantly built, developed and maintained in every organizational unit operating on the electronic market, with a special look at factors, i.e.: "common values", ,"communication", or ",experience and qualifications". 
It is also worth mentioning, that companies that create their business based on the trust are perceived as „optimistically economical” (Stickley et al. 2009). This is because a company with a high degree of trust is more flexible in adapting to prevailing e-market conditions, is not afraid of changes, shows a quick ability to absorb new information and to share it with others. Such a company also cultivates existing relationships with its business partners and is involved in building new and strong ones, while demonstrating a broad competence horizon, integrity and credibility intact as well as a friendly and kind disposition towards the other side of the interaction - the motto that "benevolence trust can affect the relationships of e-commerce partners by bonding them" (Leaquiddin et al. 2010). The fulfillment of all the above-mentioned requirements, which put the functioning of enterprises in the electronic market in a good light, proves the constant supply of value to business partners and maintaining positive relations with them, which in turn generates measurable values and stable development of the e-enterprise.

\section{Summary}

Factors Shaping Inter-organizational Trust in e-Commerce Based on Literature Review

The article is devoted to identifying external and internal factors that shape inter-organizational trust in e-commerce. Studying how trust between e-commerce partners is built, four key B2B trust spheres were analyzed based on literature. After analyzing thirteen research reports, the factors shaping B2B trust are presented due to their frequency of occurrence in the reports. Research has shown that among the many factors determining B2B trust, the greatest value in interactions between e-commerce partners lies in the factors, i.e.: „common values", „communication”, „experience and qualifications".

Keywords: factors, type of trust, inter-organizational, B2B, e-commerce.

\section{Streszczenie}

Czynniki kształtujące zaufanie międzyorganizacyjne w handlu elektronicznym na podstawie przeglądu literatury

Artykuł poświęcony jest zidentyfikowaniu czynników zewnętrznych i wewnętrznych, które kształtują zaufanie międzyorganizacyjne $\mathrm{w}$ handlu elektronicznym. Badając, $\mathrm{w}$ jaki 
sposób budowane jest zaufanie pomiędzy partnerami e-handlu, w oparciu o literaturę, przyjrzano się również czterem, kluczowym sferom zaufania B2B w świetle definicyjnym. Po przeanalizowaniu trzynastu raportów badawczych, przedstawiono czynniki kształtowania zaufania B2B, ze względu na częstotliwość ich występowania $\mathrm{w}$ raportach. Badania pokazały, że spośród wielu czynników determinujących zaufanie B2B, największa wartość $\mathrm{w}$ interakcjach między partnerami e-handlu, leży po stronie czynników, tj. ,wsspólne wartości”, ,komunikacja”, , doświadczenie i kwalifikacje".

\section{Słowa}

kluczowe: czynniki, typyzaufania, międzyorganizacyjność, B2B, handel elektroniczny.

\section{References}

1. Ando, N. and Rhee, D.K. (2009). Antecedents of Interorganizational Trust: Joint Decision-Making, Cultural Adaptation, and Bargaining Power. Journal od Asia Business Studies, 2009.

2. Barney, J. and Hansen, M. (1994), Trustworthiness as a source of competitive advantage, StrategicManagement Journal, Vol. 15, Winter, pp. 175-90.

3. Chen, X., Huang Q., Davison, R.M., Hua, Z. (2015), What Drives Trust Transfer? The Moderating Roles of Seller-Specific and General Institutional Mechanisms, International Journal of Electronic Commerce, 2015, 20:2, pp. 261-289, DOI: 10.1080/10864415.2016.1087828.

4. Chong, A., Ooi, K., Lin, B., Thang, S. (2009), Influence of interorganizational relationships on SMEs; e-business adoption, Internet Research Vol.19 No. 3, 2009 pp. 313-331.

5. Chowdhury, S. (2005), The role of affect- and cognition-based trust in complex knowledgesharing, Journal of Managerial Issues, Vol. XVII No. 3, pp. 310-26.

6. Cote, J. and Latham, C.K. (2006), Trust and commitment: intangible drivers of interorganizational performance, Advances in Management Accounting, Vol. 15, 293-325.

7. Coulter, K.S. and Coulter, R.A. (2002), Determinants of trust in a service provider: the moderating role oflength of relationship, Journal of Services Marketing, Vol. 16 No. 1, pp. 35-50.

8. Doney, P.M. and Cannon, J.P. (1997), An examination of the nature of trust in buyer-seller relationships, Journal of Marketing, Vol. 61 No. 2, pp. 35-51.

9. Ellonen, R., Blomqvist, K., Puumalainen, K. (2008), The role of trust in interorganisational innovativeness, European Journal of Innovation Management, Vol. 11 No. 2, 2008. 
10. Greenberg, P.S., Greenberg, R.H., Antonucci, Y.L. (2008), The role of trust in the governance of business process outsourcing relationships, Business Process Management Journal, Vol. 14, No. 5, 2008, DOI: 10.1108/14637150810903011.

11. Jennings, D.F., Artz, K., Gillin, L.M., Christodouloy, Ch., Determinants of trust in global strategic Alliance: armad and the Australia biomedical industry, Competentitiveness Review, Vol. 10, 2000.

12. Koźmiński, A., Relacje międzyorganizacyjne w naukach o zarządzaniu, Wollters Kluwer Polska, Warszawa 2014.

13. Kwon, I.W.G. and Suh, T. (2005), Trust, commitment and relationships in supply chain management: apath analysis, Supply Chain Management: An International Journal, Vol. 10 No. 1, pp. 26-33.

14. Mirkovski, K., Lowry, P.B. (2016), Factors that influence interorganizational use of information and communications technology in relationshipbased supply chains: evidence from the Macedonian and American wine industries, Supply Chain Management: An International Journal 21/3 (2016), pp. 334-351, DOI: 10.1108. SCM-08-2015-0343.

15. Mukherjee, D., Renn, R.W., Kedia, B.L., Mukherjee, D. (2012), Development of interorganizational trust in vitrual organizations. An integrative Framework, European Business Review, Vol. 24 No. 3, pp. 255-271, DOI: $10.1108 / 09555341211222503$.

16. Nes, E.B., (2014), Antecedents and consequences of replacing international independent intermediaries, European Business Review Vol. 26 No. 3, 2014, pp. 218-237, DOI 10.1108/EBR-09-2013-0118.

17. Pan, Y., Nam, T., Ogara, S., Lee, S. (2013), Adoption model of mobileenabled systems in supply chain, Industrial Management $\mathcal{E}$ Data Systems, Vol. 113, No. 2.

18. Ryciuk, U., (2013), Zaufanie międzyorganizacyjne- konceptualizacja, operacjonalizacja i pomiar. Przegląd organizacji, Miesięcznik "TNOiK”, Torun 2013.

19. Sahay B. (2003), Understanding trust in supply chain relationships, Industrial Management \& Data Systems, Vol. 103, No. 8, pp. 553-563, https:// doi.org/10.1108/02635570310497602.

20. Stickley, A., Ferlander, S., Jukkala, T., Carlson, P., Kislitsyna, O., Makinen, I.H., (2009)Institutional Trust in Contemporary Moscow, Europe-Asia Studies, 61:5, pp. 779-796, DOI: 10.1080/09668130902904951.

21. Sun, B., Lo, Y., (2014), Achieving alliance ambidexterity trough managing oaradoxes of cooperation. A new theoretical framework, European Journal of Innovation Management, Vol. 17, No. 2, 2014, pp. 144-165, DOI: 10.1108/ EJIM-01-2013-001.

22. Tajpal, G., Garg, R.K., Sachdeva, A., Trust among supply chain partners: a review, Measuring Buisness Excellence, Vol.17, No. 1, 2013, pp. 51-57, DOI: 10.1108/13683041311311365. 


\section{Management \\ 2020}

Vol. 24, No. 1

23. van der Meer-Kooistra, J. and Vosselman, E.G.J. (2000), Management control of interfirmtransactional relationships: the case of industrial renovation and maintenance, Accounting, Organizations and Society, Vol. 25 , pp. 51-77.

24. Wrightsman, L.S. (1964), Measurement of philosophies of human nature, Psychological Reports, Vol. 14 No. 3, pp. 743-51.

25. Yee, W.M.S. and Yeung, R.M.W. (2002), Trust building in livestock farmers: an exploratory, Study,Nutrition \& Food Science, Vol. 32 No. 4, pp. 137-44.

26. Xiao, L., Guo, Z., Ambra, J., Fu, B. (2016), Building loyalty in e-commerce. Towards a multidimensional trust- based Framework for the case of China, Chungnam National University, Daejeon, South Korea 2016. 